\title{
Acute and Sub-Chronic Oral Toxicity Evaluation of Eucalyptus Globulus Essential Oil-Water Emulsion in Mice
}

\section{Abinet Gebremickael ${ }^{1 *}$}

${ }^{1}$ Department of Biomedical Sciences, School of Medicine, College of Medicine and Health Sciences, Arba Minch University, Arba Minch, Ethiopia.

"Corresponding author: Gebremickael A, Department of Biomedical Sciences, School of Medicine, College of Medicine and Health Sciences, Arba Minch University, Arba Minch, Ethiopia, Tel: +251941235750, +251925924290; E-mail: abinetgebremickael@gmail.com and abinet.gebremickael@amu.edu.et

Received date: May 02, 2017; Accepted date: June 20, 2017; Published date: June 30, 2017

Copyright: ( 2017 Gebremickael A. This is an open-access article distributed under the terms of the Creative Commons Attribution License, which permits unrestricted use, distribution, and reproduction in any medium, provided the original author and source are credited.

\begin{abstract}
Background: plants are composed of bioactive chemicals some of which may be toxic. Therefore, scientists advocate for toxicological studies to be carried out in order to ensure the safety of drugs. Accordingly, this study was aimed to assess the possible toxic effects of Eucalyptus glubulus essential oil- water emulsion after oral administration in mice.

Methods: The essential oil used in this study was obtained by extraction of the fresh leaves of E.glubulus through hydro-distillation technique. In the acute toxicity study, the mice placed in the seven treatment groups were administered with randomly selected $0.5 \mathrm{ml} / \mathrm{kg}$ initial dose up to $3.5 \mathrm{ml} / \mathrm{kg}$ body weight spaced by $0.5 \mathrm{ml} / \mathrm{kg}$. The control animals received vehicle. All animals were gavaged the designated dose once and observed for the next two weeks. In the sub-chronic study, a control and two treatment groups, each containing twelve animals were used. Based on the findings of acute toxicity study, the two treatment groups were received 1.5 and $2.0 \mathrm{ml} / \mathrm{kg}$ body weight test doses respectively for three months in 24 hours interval. At the end study period, blood samples were taken by cardiac puncture and then, all animals were sacrificed and the vital organs were collected and processed for histopathological examination.
\end{abstract}

Results: In the acute toxicity study, some toxicity signs and deaths of mice were recorded only at doses higher than $2.0 \mathrm{ml} / \mathrm{kg}$ body weight. 1 out of 6 mice in a group treated with $3.0 \mathrm{ml} / \mathrm{kg}$ and, 4 out of 6 animals in a group treated with $3.5 \mathrm{ml} / \mathrm{kg}$ body weight test doses of the emulsion were died following the administration. Therefore, the oral route LD50 of the emulsion falls between $3 \mathrm{ml} / \mathrm{kg}$ and $3.5 \mathrm{ml} / \mathrm{kg}$. In the sub-chronic treatment, no death was recorded, and there was no statistically significant $(p>0.05)$ change in the body weight, evaluated hematological and biochemical parameters of blood. However, minor pathological changes like; pyknosis and vacuolations of hepatocytes in some liver sections, and perivascular lymphocytic infiltrations and hyaline casts in renal tubules of some kidney sections, were observed in mice treated with $2.0 \mathrm{ml} / \mathrm{kg}$ body weight test dose.

Conclusions and recommendations: The emulsion at relatively lower doses does not produce obvious toxic effects after acute and prolonged oral administration in mice. However, further investigation is needed to confirm this.

Keywords: Hydro-distillation; Eucalyptus glubulus; Emulsion; Acute; Sub-chronic; Essential oil

\section{Introduction}

Eucalyptus globulus is a tall, evergreen tree native to Australia and Tasmania [1]. The leaves and essential oil of Eucalyptus plant are traditionally used as insect repellent and pesticides, analgesic, antiinflammatory and antipyretic remedies for the symptoms of respiratory tract infections, such as cold, flu, and sinus congestion in different corners of the world [2-5]. In Ethiopia also the leaves of Eucalyptus globulus has been traditionally used directly as a natural insect repellent, boiled and the vapor is inhaled to treat influenza and chest rub, applied on livestock's skin to rid skin parasites.

Parallel with recent increasing interest in herbal medicine for the prevention and treatment of various human illnesses and animal diseases, there is increasing concern about the safety of medicinal plants. Literatures have documented severe toxic reactions from the use of herbs and spices for medication because of some toxic bioactive chemicals contained in some plants [6,7]. Inappropriate formulation and uses or lack of understanding of acute and long term effects of drugs or traditionally used medicines had led to adverse reactions that are sometimes life threatening [8].

Different investigations on various traditionally used medicinal plants and drugs have showed adverse effects on several blood parameters, liver and kidneys in experimental animals. These tissues or organs are found common targets of toxic insult of various drugs because of their central role in the transport, metabolism and excretion of foreign chemicals from the body.

A 5\% Eucalyptus glubulus essential oil-water emulsion prepared for the control of major animal ectoparasites has showed high acaricidal 
efficacy on earlier findings of a collaborative work between the Ethiopian Public Health Institute (EPHI) and Addis Ababa University (AAU) / Faculty of Veterinary Medicine (FVM), Ethiopia [9, 36]. Their finding also revealed that the emulsion was tested for skin sensitization potential in small ruminants and was safe. However, the investigators reported that the infested small ruminants were aggressively licked and internalized the emulsion following a topical treatment.

In view of all the above facts, it was found compulsory to carryout toxicological evaluation to ensure the safety of the emulsion when internalized $[10,11]$. Accordingly, this study was aimed to assess the acute and sub-chronic toxic effects of the emulsion after oral administration in mice.

\section{Materials and Methods}

\section{Study setup}

The study was chiefly conducted at Traditional and Modern Medicine Research Directorate (TMMRD) Laboratories of EPHI, Addis Ababa, Ethiopia. Tissue processing and photomicrography of tissue sections was conducted at the Histology laboratory of department of Anatomy, College of Health Science, AAU.

\section{Plant material collection, extraction and preparation of an emulsion}

The leaves of Eucalyptus globulus were collected from Wondogenet Agricultural Research Center (WARC) experimental plot, located in Southern Nations, Nationalities and Peoples' Region (SNNPR), $260 \mathrm{~km}$ south of Addis Ababa, the capital city of Ethiopia. A taxonomist in the TMMRD of EPHI did the botanical identification and authentication of the collected plant specimens.

Freshly collected leaves of E. globulus were cleaned by using distilled water and air-dried at room temperature under shade. Then, chopped in to smaller pieces and the essential oil extraction was carried out by using hydrodistillation technique in a modified Clevenger-type apparatus [12]. The obtained oil was then filtered and then concentrated using rotary evaporator. An emulsion comprising $5 \%$ concentration of E. globulus essential oil in water by using $2 \%$ Tween 80 as emulsifier was prepared for subsequent experiment.

\section{Experimental animal preparation}

All animals used in this study were bred and reared at the animal house of the EPHI and transported to the TMMRD Laboratories. Experiments were conducted on healthy adult male and female albino Swiss mice aged 6-8 weeks weighing 23-30g. The male and female mice were kept in separate aluminum cages with bedding of clean paddy husk in well ventilated house at maintained temperature $(22 \pm 30 \mathrm{C})$ and 12 hours light/dark cycles till the end of the experiment. All animals had a free access to conventional laboratory rodent pellet diet standard for biomedical researches and drunken tap water ad libitum. The mice were acclimatized to laboratory conditions for a week prior to the experimental protocol to minimize any nonspecific stress [13].

\section{Acute toxicity study}

Acute toxicity test was started with randomly selected low initial dose $(0.5 \mathrm{ml} / \mathrm{kg}$ body weight $)$ and increased to additional six higher doses spaced by $0.5 \mathrm{ml} / \mathrm{kg}$. A total of eight groups each consisting of six female Swiss albino mice were used. All groups of mice were fasted for 4 hours prior to administration and for 2 hours after the administration of the emulsion. At the end of the fasting period, the body weight of each mouse was recorded before dosing and the doses were calculated and administered to the mice in the treatment groups based on their fasted body weight. Each treated group (G-I to VII) received designated doses to produce test groups with a range of toxic effects and mortality rates in 72 hours observation following the administration. The control group (G-VIII) received the vehicle comprising only $2 \%$ Tween- 80 and water. The administration procedure was done by gavages using a ball-tipped stainless steel feeding needle. The animals were then observed continuously for 4 hours in 30 minutes interval and in every 24 hours for 14 days. Any signs of toxicity and mortality were recorded.

At the end of the second week, the final weight of each mouse was recorded and then sacrificed by cervical dislocation. All mice were subjected to careful examination of the skin and comprehensive gross pathological observations were carried out on abdominal viscera's, the stomach, kidneys and the liver in particular.

\section{Sub-chronic toxicity study}

The sub-chronic toxicity study was carried out through twelve weeks (84 days). In this study, two doses $(1.5 \mathrm{ml} / \mathrm{kg}$ and $2.0 \mathrm{ml} / \mathrm{kg}$ body weight) were selected based on the findings in acute toxicity study. The control group animals were received vehicle. In accordance with the Organization for Economic and Co-operation and Development (OECD) guideline [14], the calculated doses of an emulsion were diluted by additional water to raise the volume administered at one time to $1 \mathrm{ml} / 100 \mathrm{~g}$ body weights of a mouse in 24 hours interval throughout the study period.

For repeated dose sub chronic toxicity study, thirty six albino Swiss mice were used. Before dosing, they were assigned to three groups (GI, G-II, and G-III) each consisting of twelve animals of both sex. The male and female mice were kept in separate aluminum cages and the cages were labeled appropriately. The control group (G-I) received vehicle while G-II and G-III were administered with 1.5 and $2.0 \mathrm{ml} / \mathrm{kg}$ body weight test doses of the emulsion respectively.

Body weight of each mouse was recorded before dosing, once weekly throughout the study period, and at the end the experiment. The mean body weight and final weight gains or losses of each group as well as the difference as compared to the control groups were calculated.

\section{Hematological and biochemical analyses}

24 hours after the last oral administration of the emulsion, blood samples were collected by cardiac puncture. Some of the blood samples obtained from each mouse were then collected in separate test tubes with Ethylene Diamine Tetra-acetic Acid (EDTA) and the other in plain test tubes. Blood samples from EDTA containing test tubes were immediately processed for hematological parameters to dermine hematocrit (HCT), hemoglobin concentration (HGB), mean corpuscular hemoglobin $(\mathrm{MCH})$, mean corpuscular hemoglobin concentration (MCHC), mean corpuscular volume (MCV), platelet count (PLC), red blood cell count (RBC), White blood cell count (WBC) using Automated Hematological Analyzer, SYSMEX XT-1800i (SYSMEX CORPORATION, Japan). Blood samples in the plain test tubes were allowed to stand for 3 hours for complete clotting and then centrifuged at $5000 \mathrm{rpm}$ for 15 minutes using a bench top centrifuge 
Page 3 of 7

(HUMAX-K, HUMAN-GmbH, Germany) to obtain the sera. Biochemical analysis of the sera was done by using COBAS INTEGRA 400 plus Analyzer (ROCH DIAGNOSTICS, Japan) and, the concentrations of Alanine Transaminase (ALT), Aspartate Transaminase (AST), total bilirubin, urea, uric acid and creatinine were determined.

\section{Histopathological studies}

The liver and kidneys collected from all mice were processed through routine tissue processing technique and the specimens were stained using Hematoxylin and Eosin staining method for histopathological examination. Stained tissue sections were carefully examined under binocular compound light microscope (LEICA DM 750, Germany). After examination, photomicrograph of selected samples of liver and kidney sections of both treated and control group animals were taken under a magnification X200 and X400 by using (LEICA ICC50 HD, Germany) automated built-in digital photo camera.

\section{Statistical Analysis}

All data were organized and analyzed by using Statistical Package for Social Sciences (SPSS) version-16 software packages. Values of the body weight changes, hematological and biochemical parameters were analyzed and the results were expressed as $\mathrm{M} \pm$ SEM (Mean \pm standard error of the mean). Differences between the treated and control groups were compared using one-way analysis of variance (ANOVA), followed by Dunnett's t-test to determine their level of significance. Differences at $p<0.05$ were considered statistically significant.

\section{Ethical consideration}

The study design and the use of the experimental animals were reviewed and approved by the Institutional Review Board (IRB) of the school of Medicine, College of Health Science, AAU. The handing of animals was conducted in accordance with international guidelines of the care and use of laboratory animals.

\section{Results}

\section{Acute toxicity study}

The acute toxicity evaluation was aimed to assess treatment related toxic effects and identify rough safety margin of the emulsion. In view of that, the emulsion did not show any sign of toxicity and mortality of mice after single oral administration of test doses up to $2.0 \mathrm{ml} / \mathrm{kg}$ body weight. However, test doses at and above $2.5 \mathrm{ml} / \mathrm{kg}$ body weight, showed toxic effects like restlessness immediately after the administration followed by debilitation, reduced food and water consumption, gather together and piloerection. The symptoms however disappeared in survived mice after some washing periods, mostly after a day.

Mortality was recorded only at 3.0 and $3.5 \mathrm{ml} / \mathrm{kg}$ body weight doses. One mouse out of six animals in G-VI that received $3.0 \mathrm{ml} / \mathrm{kg}$ body weight test dose was died overnight following the administration, and four mice out of six animals in G-VII were died within 24 hours after receiving $3.5 \mathrm{ml} / \mathrm{kg}$ body weight dose. The gross post mortem examination showed no noticeable change in the appearance of observed internal organs; the stomach, liver and kidney, in all groups of mice.

\section{Sub-chronic toxicity study}

In the sub chronic toxicity study, two test doses, $1.5 \mathrm{ml} / \mathrm{kg}$ and $2.0 \mathrm{ml} / \mathrm{kg}$, were selected based the finding of acute toxicity evaluation. These doses of the emulsion did not produced any treatment related toxicity signs and death of mice after single oral administration in mice. Accordingly, this sub-chronic study was conducted to assess effect of the emulsion on some blood parameters, body weight, liver, and kidney after prolonged oral administration in mice. The 12 subsequent weeks daily treatment with the emulsion did not result in statistically significant ( $p>0.05)$ changes in any of the hematological parameters of the mice at both 1.5 and $2.0 \mathrm{ml} / \mathrm{kg}$ body weight test doses as compared to the controls (Table 1).

\begin{tabular}{|l|l|l|l|}
\hline Hematological Parameters & Control (G-I) & $\mathbf{1 . 5 m l / k g ~ d o s e ~ ( G - I I ) ~}$ & 2.0ml/kg dose (G-III) \\
\hline WBC $(x 103 / \mu \mathrm{L})$ & $4.5 \pm 1$ & $2.7 \pm 0.2(0.57)$ & $5.4 \pm 1.8(0.84)$ \\
\hline RBC $(\times 106 / \mu \mathrm{L})$ & $9.6 \pm 0.28$ & $9.2 \pm 0.3(0.96)$ & $6 \pm 1.8(0.09)$ \\
\hline HGB $(\mathrm{g} / \mathrm{dL})$ & $14.6 \pm 0.43$ & $14.5 \pm 0.37(0.98)$ & $13.9 \pm 0.77(0.63)$ \\
\hline HCT $(\%)$ & $44.6 \pm 0.93$ & $41.5 \pm 0.41(0.44)$ & $39.5 \pm 2.7(0.13)$ \\
\hline MCV $(\mathrm{fL})$ & $46.5 \pm 0.43$ & $45.3 \pm 0.6(0.84)$ & $46 \pm 0.96(0.99)$ \\
\hline MCH $(\mathrm{pg})$ & $15.2 \pm 0$ & $15 \pm 0.04(0.98)$ & $14 \pm 0.77(0.14)$ \\
\hline MCHC $(\mathrm{g} / \mathrm{dL})$ & $32.7 \pm 0.3$ & $33.2 \pm 0.36(0.98)$ & $30.7 \pm 2(0.42)$ \\
\hline PLT $(\mathrm{x} 103 / \mu \mathrm{L})$ & $977.3 \pm 44.9$ & $366 \pm 151.9(0.09)$ & $695 \pm 331.6(0.65)$ \\
\hline Values are expressed as Mean \pm SEM. The figures in brackets indicate the calculated $\mathrm{p}$ values of the treatment groups as compared to the control. \\
\hline
\end{tabular}

Table 1: Comparison of the evaluated hematological parameters between the mice treated with both doses of E.globulus essential oil-water emulsion and vehicle control. 
Treatment with both doses of the emulsion did not also bring statistically significant $(\mathrm{p}>0.05)$ changes in any of the selected serum biochemical parameters as compared to the control (Table 2).

\begin{tabular}{|l|l|l|l|}
\hline Biochemical Parameters & Control (G-I) & $\mathbf{1 . 5 m l / k g ~ d o s e ~ ( G - I I ) ~}$ & 2.0ml/kg dose (G-III) \\
\hline Uric Acid (mg/dL) & $4.88 \pm 2.16$ & $3.71 \pm 0.24(0.99)$ & $5.67 \pm 3.08(1.00)$ \\
\hline ALT (IU/L) & $84.2 \pm 8.52$ & $86.75 \pm 13.8(0.99)$ & $96.5026 .5(0.90)$ \\
\hline AST(IU/L) & $142.5 \pm 29.47$ & $184.67 \pm 17.18(0.86)$ & $258.8 \pm 57.92(0.13)$ \\
\hline Total Bilirubin & $1.88 \pm 0.41$ & $2.42 \pm 0.02(0.95)$ & $2.93 \pm 0.61(0.68)$ \\
\hline Urea (mg/dL) & $56.5 \pm 6.6$ & $52.5 \pm 1.04(0.99)$ & $57 \pm 3.34(1.00)$ \\
\hline Creatinine (mg/dL) & $0.57 \pm 0.12$ & $0.59 \pm 0.23(1)$ & $0.61 \pm 0.06(0.99)$ \\
\hline Values are expressed as Mean \pm SEM. The figures in brackets indicate the calculated p values of the treatment groups as compared to the control. \\
\hline
\end{tabular}

Table 2: Comparison of the evaluated biochemical parameters between the mice treated with both doses of E.globulus essential oil-water emulsion and vehicle control.

During the period of 84 days of toxicity evaluation, there was no noticeable change in the general behavior and gross visceral examination of treated mice. Moreover, there was no toxicity related death report throughout the period of study.

Final body weight gains were recorded in all groups of mice at the end of the study period. As summarized on Table 3 below, there was no significant body weight difference between the control and treatment group animals.

\begin{tabular}{|c|c|c|c|c|}
\hline Group & Weak 1 & Weak 2 & Weak 3 & Weak 4 \\
\hline Control & $26.7 \pm 3.1$ & $31.1 \pm 2.1$ & $31.2 \pm 2.4$ & $36.9 \pm 4.0$ \\
\hline $1.5 \mathrm{ml} / \mathrm{kg}$ & $\begin{array}{l}27.7 \\
(0.72)\end{array} \pm 1.9$ & $\begin{array}{l}30.1 \\
(0.84)\end{array}$ & $30.3 \pm 3.3(1.0)$ & $33.1 \pm 4(0.21)$ \\
\hline $2.0 \mathrm{ml} / \mathrm{kg}$ & $\begin{array}{l}28.5 \\
(0.23)\end{array}$ & $\begin{array}{l}28.5 \\
(0.15)\end{array}$ & $28.7 \pm 2.9(1.0)$ & $\begin{array}{l}32.1 \\
(0.06)\end{array} \pm 5.1$ \\
\hline Group & Weak 5 & Weak 6 & Weak 7 & Weak 8 \\
\hline Control & $37.1 \pm 3.9$ & $38.0 \pm 3.8$ & $38.2 \pm 3.6$ & $39.0 \pm 4.3$ \\
\hline $1.5 \mathrm{ml} / \mathrm{kg}$ & $34.4 \pm 3(0.33)$ & $\begin{array}{l}35.6 \pm 3.6 \\
(0.58)\end{array}$ & $\begin{array}{l}33.2 \pm 3.8 \\
(0.07)\end{array}$ & $\begin{array}{l}35.0 \pm 3.6 \\
(0.26)\end{array}$ \\
\hline $2.0 \mathrm{ml} / \mathrm{kg}$ & $\begin{array}{l}34.7 \\
(0.41)\end{array}$ & $\begin{array}{l}33.8 \pm 4.5 \\
(0.12)\end{array}$ & $35 \pm 2.8(0.27)$ & $\begin{array}{l}34.4 \quad \pm \quad 4.7 \\
(0.17)\end{array}$ \\
\hline Group & Weak 9 & Weak 10 & Weak11 & Weak 12 \\
\hline Control & $39.3 \pm 4.1$ & $40.4 \pm 4.4$ & $40.4 \pm 4.4$ & $40.0 \pm 3.8$ \\
\hline $1.5 \mathrm{ml} / \mathrm{kg}$ & $\begin{array}{l}35.0 \pm 3.6 \\
(0.19)\end{array}$ & $\begin{array}{l}35.9 \\
(0.06)\end{array} \pm 3.3$ & $\begin{array}{l}36.0 \pm 3.6 \\
(0.10)\end{array}$ & $\begin{array}{l}35.4 \\
(0.19)\end{array} \quad \pm \quad 4.9$ \\
\hline $2.0 \mathrm{ml} / \mathrm{kg}$ & $\begin{array}{l}34.4 \\
(0.11)\end{array}$ & $\begin{array}{l}36.1 \\
(0.09)\end{array}$ & $\begin{array}{l}35.3 \pm 2.2 \\
(0.07)\end{array}$ & $39.5 \pm 3.3(1.0)$ \\
\hline
\end{tabular}

Values are expressed as Mean \pm SEM. The figures in brackets indicate the calculated $p$ values of the treatment groups as compared to the control.

Table 3: Mean body weights (in gram) of mice treated with 1.5 and $2.0 \mathrm{ml} / \mathrm{kg}$ body weight doses of E.globulus essential oil-water emulsion as compared to the control group in consecutive twelve weeks measurement.

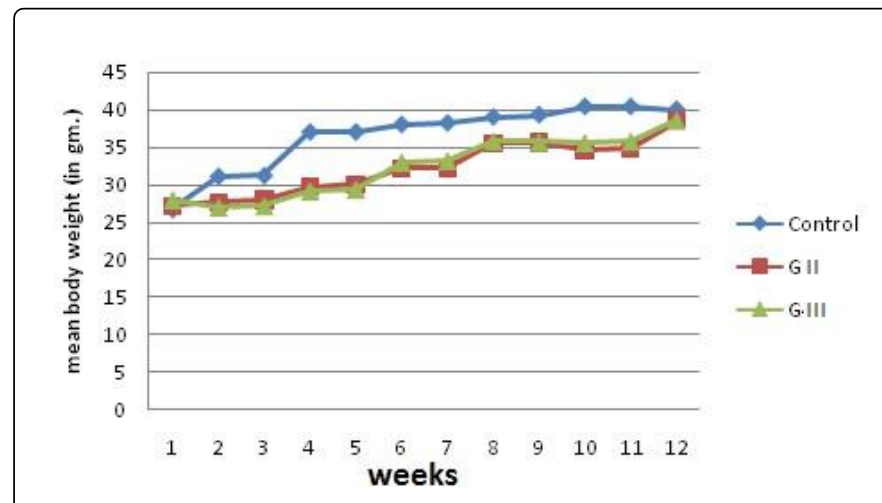

Figure 1: Comparison of body weight change between mice treated at $1.5 \mathrm{ml} / \mathrm{kg}$ (GII) and $2.0 \mathrm{ml} / \mathrm{kg}$ (GIII) body weight doses of the emulsion and the control group, Histopathological Analysis.

Microscopic examinations of liver sections of control group mice (Figure 2A) showed the normal architecture of the structural units of liver. The general microscopic architecture of the liver sections of mice treated with $1.5 \mathrm{ml} / \mathrm{kg}$ body weight dose (Figure $2 \mathrm{~B}$ ) of the emulsion was also unaffected after 84 days treatment. However, in some areas of the liver sections of mice treated at $2.0 \mathrm{ml} / \mathrm{kg}$ body weight dose (Figure $2 \mathrm{C}$ ), the general hepatolobular architecture was altered, pyknosis, clear spaces in the cytoplasm (vacuolations) of hepatocytes and focal necrosis were observed.

Kidney sections of mice in the control group showed the normal microscopic organization (Figure 3A). Examination of kidney sections of mice treated with the emulsion at both $1.5 \mathrm{ml} / \mathrm{kg}$ (Figure $3 \mathrm{~B}$ ) and $2.0 \mathrm{ml} / \mathrm{kg}$ doses (Figure 3C) also indicated no significant structural disturbance. However, pyknosis of renal tubular epithelial cells and widening of tubular lumen was observed in sections of kidney obtained from mice treated with $2.0 \mathrm{ml} / \mathrm{kg}$ body weight dose (Figure 3C). Besides, hyaline casts in renal tubules and perivascular lymphocytic infiltrations were also observed in small areas of kidney 
sections of mice treated with $2.0 \mathrm{ml} / \mathrm{kg}$ dose of the emulsion (Figure 3D).

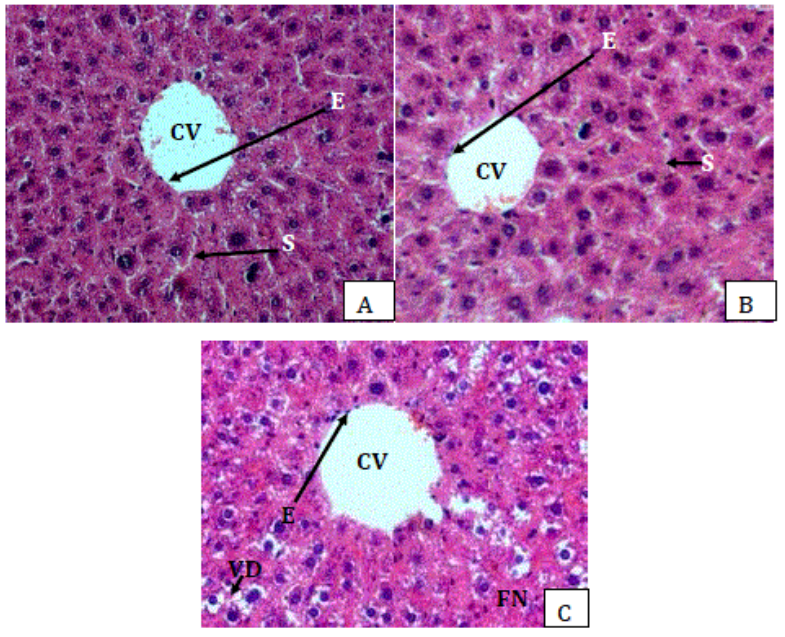

Figure 2: Photomicrographs of liver sections of control group mice (A), mice treated with $1.5 \mathrm{ml} / \mathrm{kg}$ body weight dose (B), mice treated with $2.0 \mathrm{ml} / \mathrm{kg}$ body weight dose $(\mathrm{C}) . \mathrm{CV}=$ Central vein, $\mathrm{E}=$ Endothelial cells, $\mathrm{S}=$ Sinusoids, $\mathrm{FN}=$ Focal necrosis, $\mathrm{VD}=$ vacuolar degeneration. (Sections were stained with $\mathrm{H} \& \mathrm{E}, \mathrm{X} 400$ ).
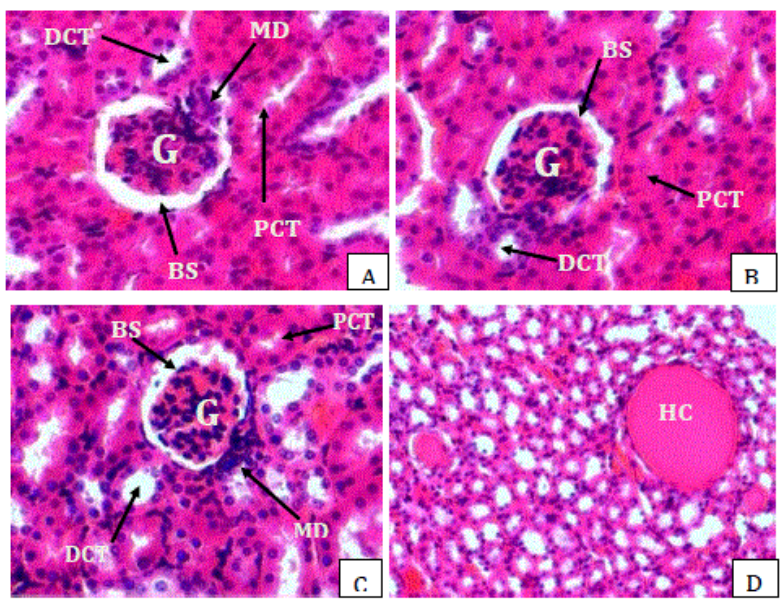

Figure 3: Photomicrographs of kidney sections of mice in the control group (A), mice treated with $1.5 \mathrm{ml} / \mathrm{kg}$ dose (B), and $2.0 \mathrm{ml} / \mathrm{kg}$ dose $(\mathrm{C}, \mathrm{D}, \mathrm{E})$ of the emulsion. $\mathrm{DCT}=$ Distal convoluted tubule, $\mathrm{PCT}=$ Proximal convoluted tubule, $\mathrm{MD}=$ Macula densa, $\mathrm{BS}$ $=$ Bowman's space, $\mathrm{G}=$ Glomerulus, $\mathrm{I}=$ Infiltration, and $\mathrm{HC}=$ Hyaline casts. (Sections were stained with H \& E, X400).

\section{Discussion}

Though Eucalyptus oil is generally regarded as safe by US, toxicity studies are conducted to characterize the potential toxic effects the drug can produce. This is usually performed by implementation of general preclinical toxicity experiments in animals [15]. In this study we conducted acute and sub-chronic toxicity study to evaluate the safety of E.globulus essential oil-water emulsion in mice. As per the OECD guideline [14], all animals had free access to conventional laboratory rodent diet and drunken tap water ad libitum. This was aimed to maintain consistency of the diet and avoid diet linked health effect on study animals.

The first toxicity test performed in this study was evaluation of the acute toxicity from a single dose exposure of the emulsion in mice. Accordingly, the E.globulus essential oil-water emulsion did not result in any mortality of the treated mice after oral administration of single doses up to $2.5 \mathrm{ml} / \mathrm{kg}$ body weight test doses. In the first four doses, $0.5 \mathrm{ml} / \mathrm{kg}, 1.0 \mathrm{ml} / \mathrm{kg}, 1.5 \mathrm{ml} / \mathrm{kg}$, and $2.0 \mathrm{ml} / \mathrm{kg}$, signs of gross toxicity or abnormal behavioral changes were not observed throughout the two weeks observation period. One of the six mice in a group treated with $3.0 \mathrm{ml} / \mathrm{kg}$ and, four of the six animals in a group treated with $3.5 \mathrm{ml} / \mathrm{kg}$ body weight test doses of the emulsion were died following the administration. Therefore, the oral route LD50 of the emulsion falls between $3 \mathrm{ml} / \mathrm{kg}$ and $3.5 \mathrm{ml} / \mathrm{kg}$ body weight doses. Our finding of acute toxicity study is in complement with a related toxicity study report by Zhiqiang et al., [16], in which less mortality and mild signs of toxicity were observed following oral administration of Eucalyptus oil-water emulsion at doses up to $3267 \mathrm{mg} / \mathrm{kg}$ in rats.

Sub-chronic toxicity study was conducted with repeated daily administration of 1.5 and $2.0 \mathrm{ml} / \mathrm{kg}$ body weight doses of the emulsion to investigate its long term effects on some selected parameters. The three months daily treatment with the emulsion at both doses did not show any toxicity related mortalities and changes in general health, behavior, motor activities, and growth. Hence, it can be concluded that the emulsion has no effect on growth and normal functions of the mice at low doses [16].

One of the sensitive indices of toxicity assessment after exposure to toxic substances is body weight change [17]. In this study, the body weight changes of mice treated with both 1.5 and $2.0 \mathrm{ml} / \mathrm{kg}$ body weight test doses of E.globulus essential oil-water emulsion was not significantly different from the control $(\mathrm{P}>0.05)$. Both treatment and control group mice were showed overall gain in body weight with time over the period of the experiment, and this indicate positive health status of the animals or safety of the emulsion at lower doses [18, 19, 20,21].

The extent of toxic effect of drugs can be determined by assessment of haematological parameters, because blood profile usually provides important information on the response of the body to injury or lesion, deprivation and stress [22, 23]. In clinical pathology, the core haematology tests recommended include total WBC count, RBC count, platelet count (PLT), hemoglobin concentration (Hgb), HCT, $\mathrm{MCV}, \mathrm{MCH}$, and MCHC [24].

Red blood indices such as the mean corpuscular volume (MCV), mean corpuscular hemoglobin $(\mathrm{MCH})$ and mean corpuscular hemoglobin concentration (MCHC) are the most useful indicators in the diagnosis of anemia in most animals [25, 26]. Effect of the emulsion on MCV, MCH, and MCHC was not significant ( $p>0.05)$ in both treated groups as compared to the control. These observations demonstrate that the emulsion does not produce toxic effect on red blood cells, like change in the size of RBC and Hgb weight per RBC, at low doses in mice. The changes in $\mathrm{RBC}$ count, average haemoglobin (Hgb) and hematocrite (HCT) levels of treated group animals were also insignificant $(p>0.05)$ as compared with the control. 
Sub chronic administration of both doses of the emulsion used in this study did not significantly change $(\mathrm{p}>0.05)$ the total WBC count as compared to the control. This result may indicate that the emulsion does not possess chemicals capable of inducing either leukocytosis or leucocytopenia. Besides, the platelets count indicated that the emulsion also does not induce thrombocytopenia or thrombocytosis at both doses after 12 weeks treatment [26].

Serum biochemical parameters have significant importance to evaluate changes produced by a toxicant. Elevated serum levels of enzymes produced by the liver or nitrogenous wastes to be excreted by the kidney might be indications to their spillage into the blood stream as a result of necrosis of the tissues [23,27].

Liver function tests include several serum chemistries that reflect the state of liver function. The most commonly used serum liver chemistry tests include serum transaminases (alanine aminotransferase (ALT) and aspartate aminotransferase (AST)). Injuries to liver cells allow the escape of these enzymes and raise their levels in the blood [28]. However, in Swiss albino mice treated with both doses of the emulsion tested in this study, there was no significant change on the serum level of ALT and AST as compared to the vehicle received control. This indicates that the emulsion does not cause significant hepatic damage after prolonged oral administration at relatively low doses.

Kidney function test is a collective term for a variety of individual tests and procedures that can be done to evaluate how well the kidneys are functioning. Many conditions can affect the ability of kidneys to carry out their vital functions. A decline or failure of kidney function can result in a buildup of metabolic waste products in the blood. Therefore, the measurement of concentrations of various chemicals in the blood normally regulated by the kidneys can help to determine the cause and extent of kidney dysfunction. Accordingly, renal function can be assessed by measuring the levels of plasma creatinine, urea and uric acid concentrations [29]. The serum level of creatinine, urea and uric acid concentrations in mice treated at both doses of the emulsion did not show significant alteration after twelve weeks oral administration. This suggests that the emulsion does not cause significant alteration in the renal function at doses tested by the present sub chronic toxicity study in mice.

The present histopathological examination indicated that some of the liver sections obtained from mice treated with the emulsion at $2.0 \mathrm{ml} / \mathrm{kg}$ body weight test dose showed focal necrosis, pyknosis, vacuolar degeneration, and distorted general architecture. Pyknosis, which appeared chiefly in liver sections of mice treated at $2.0 \mathrm{ml} / \mathrm{kg}$ dose, occurs when a cell receives a signal to initiate apoptosis [32-35]. Damage from toxic or immunologic insult may cause hydropic degeneration of hepatocytes in which cells take on a swollen, edematous appearance with irregularly clumped cytoplasm and vacuolations [35]. This result is in line with the finding of Shehata et al. [37]. The presence of pyknosis and protoplasmic changes like vacuolation in swollen hepatocytes possibly points potential morphologic evidence of necrosis or degeneration [32-35].

The distorted general architecture of liver in the experimental group treated with $2.0 \mathrm{ml} / \mathrm{kg}$ body weight test dose was possibly due to the observed abnormal changes in hepatocytes. Abnormal changes in the structure of the hepatocytes also result in distortion of the general liver microscopic architecture including eradication of some of the sinusoidal spaces [31]. However, all these changes were not accompanied by significant change in any of the biochemical markers of liver injury tested in this study. This result may indicate that the observed pathological changes were minor or focal and hence, the functional reserve of the liver masks the clinical importance of early liver damage [35].

In this sub chronic toxicity study, the general histological architecture of kidney sections of mice in all experiment groups was not affected. However, some sections of kidney obtained from mice treated with the emulsion at $2.0 \mathrm{ml} / \mathrm{kg}$ body weight test dose were showed widening of tubules, focal perivascular lymphocytic infiltrations and elementary homogenous hyaline casts in tubules. Being focal and minor, the observed changes are not necessary indicators of renal disease or injury [30].

\section{Conclusion and Recommendations}

It can be concluded from the findings of the present study that 5\%Eucalyptus globulus essential oil-water emulsion does not produce significant toxic effect after acute and sub chronic oral treatment at doses up to $2.0 \mathrm{ml} / \mathrm{kg}$ body weight. The observed pathological change in the liver and kidneys is minor; hence, did not affect their functions and it seems dose dependent. However, further toxicological investigation is recommended on other vital internal organs as well as on non-rodent species to confirm this finding.

\section{Author Contribution}

AG has designed the study, conducted the experiment, recorded, analyzed and interpreted the data, and prepared the manuscript.

\section{Conflict of Interest}

The author reports no conflicts of interest in this work.

\section{Acknowledgment}

I would like to acknowledge the TMMRD of EPHI for providing all necessary research materials including experimental animals and allowing us to use their laboratories, the Department of Anatomy, AAU, for allowing us to use histology laboratory. I am also grateful to Arba Minch University.

\section{References}

1. Aglal AA, Nwara AM, Ali AAI (2010) Toxicity of Aqueous Extract of Eucalyptus in Swiss Albino Mice, Suez Canal Vet Med J, 1: 199-214.

2. Silva J, Abebe W, Sousa SM, Duarte VG, Machado MIL et al. (2003) Analgesic and anti-inflammatory effects of essential oils of eucalyptus. Biores, 89: 277-283.

3. Toloza AC, Lucia A, Zerba E, Masuh H, Picollo MI (2008) Interspecifi hybridization of eucalyptus as a potential tool to improve the bioactivity of essential oils against permethrin-resistant head lice from Argentina, Bioresour Technol, 99: 7341-7347.

4. Yang YC, Choi HC, Choi WS, Clark JM, Ahn YJ (2004) Ovicidal and adulticidal activity of Eucalyptus globulus leaf oil terpenoids agains Pediculus humanus capitis (Anoplura: Pediculidae), J Agric Food Chem 52: $2507-2511$

5. Li H, Huang L, Zhou A, Li X, Sun J (2009) Study on anti-inflammatory effect of different chemotype of Cinnamomum camphora on rat arthritis model induced by Freund's adjuvant. Zhongguo Zhong Yao Za Zhi 34: 3251-3254. 
6. Oduola T, Bello I, Adeosun G, Ademosun A, Raheem G (2010) Hepatotoxicity and nephrotoxicity evaluation in wistar albino rats exposed to Morinda lucida leaf extract, N. American J, $5: 230-233$.

7. Tyler VE (1994) Herbs of Choice, The Therapeutic Use of Phytomedicinals. Binghamton NY, Haworth Press Inc.

8. Saad B, Azaizeh H, Abu-Hijleh G, Said O (2006) Safety of traditional Arab herbal medicine, Evid Based Complement Alternat Med, 4: 433-439.

9. Getachew A (2013) Development of plant based medicines against major Ectoparasites of ruminants Accomplishments and future directions, The Ethiopian Public Health Institute Proceedings of the Scientific Review Workshop on the Ongoing Efficacy and Safety Investigations of Traditionally Used Medicinal Plants in Ethiopia, Ethiopia.

10. Oyewole IO, Magaji ZJ, Awoyinka OA (2007) Biochemical and toxicological studies of aqueous extract of Tithonia diversifolia, $\mathrm{J}$ of Med Plants Res 2:30-33

11. Idu M, Ataman JE, Akhigbe AO, Omogbai EKI, Amaechina F et al. (2006) Effect of Stachytarpheta jamaicensis L, J of Med Sciences 4: 646-649.

12. Kawther FA (2007) Antimicrobial Activity of Essential Oils of Some Medicinal Plants from Arab Saudi, Saudi J of Biol, 1:53-60.

13. Vipul G, Nilesh P, Ventral N, Nandakumar K, Gouda T, et al (2007) Hepathoprotective activity of alcoholic and aqueous extract, Indian $\mathrm{J}$ of Pharmac, 39: 43-47.

14. (2001) OECD Guidelines for Testing of Chemicals, Acute Oral Toxicities up and down Procedure 425: 1-26.

15. Farzamfar B, Abdollahi M, Ka'abinejadian S, Heshmat R, Shahhosseiny MH (2008) Sub-chronic toxicity study of a novel herbal-based formulation (Semelil) on dogs, DARU J of Pharm. Sciences 1: 15-19.

16. Zhiqiang H, Ruizhang F, Fa X, Xu S, Zhongqiong Y, et al. (2014) Acute and subchronic toxicity as well as evaluation of safety pharmacology of eucalyptus oil-water emulsions, Int J Clin Exp Med 12: 4835-4845.

17. Vahalia MK, Thakur KS, Nadkarni S, Sangle VD (2011) Chronic toxicity study for Tamra Bhasma (A Generic Ayurvedic Mineral Formulation) in laboratory animals, Recent Res in Science and Tech, 11: 76-79.

18. Lu FC (1996) Basic toxicology fundamentals, target organs and risk assessment, Taylor and Francis.

19. Tofovic SP, Jackson EK (1999) Effects of long-term caffeine consumption on renal function in spontaneously hypertensive heart failure prone rats, $\mathrm{J}$ Cardiovasc Pharmacol, pp: 360-366.

20. Fandohan P, Gnonlonfin B, Laleye A, Gbenou JD, Darboux R et al. (2008) Toxicity and gastric tolerance of essential oils from Cymbopogon citratus, Ocimum gratissimum and Ocimum basilicum in Wistar rats, Food Chem, 7: 2493-2497.

21. Blanco MM, Costa CARA, Freire AO, Santos Jr JG, Costa M (2009) Neurobehavioural effect of essential oil of Cymbopogon citratus in mice, Phytomedicine, 16: 265-270.

22. Raza M, Al-Shabanah OA, El-Hadiyah TM, Al-Majed AA (2002) Effect of prolonged vigabatrin treatment on haematological and biochemical parameters in plasma, liver and kidney of Swiss albino mice, Scientia Pharmaceutica, 2: 135-145.

23. Rahman MF, Siddiqui MKJ, Jamil K (2001) Effects of vepacide (Azadirachta indica) on aspartate and alanine aminotransferase profiles in a sub-chronic study with rats, Human and Experi Toxico, 20: 243-249.
24. Weingand K, Brown G, Hall R, Davies D, Gossett K, et al. (1996) Harmonization of animal clinical pathology testing in toxicity and safety studies, Fundam and Appl Toxicology, 29:198-201.

25. Akpamu U, Nwaopara AO, Izunya AM, Oaikhena GA, Okhiai O, et al (2011) A comparative study on the acute and chronic effect of ora administration of Yaji (a complex Nigerian meat sauce) on some hematological parameters, British J of Pharmacol and Toxico, 2: 108-112.

26. Rogers K (2011) The Human Body, Blood Physiology and Circulation, Britannica Educational Puplishing.

27. Prakash SEL, Manavalan R (2011) Acute toxicity studies of Andrographolide, Res J of Pharmac, Biol and Chem Sciences, 3: 547-552.

28. Thapa BR, Walia A (2007) Liver function test and their interpretation, Indian $\mathrm{J}$ of Pediatrics, 74: 67-75.

29. Hanisa H, Hadijah H, Rasedee A, Tarmizi AS (2011) Sub-acute ora administrations of Cymbopogon citratus stem infusion and its effects on blood biochemical parameters, body and organ weights in rats, J. Trop. Agric. and Fd. Sc, 1:000-000.

30. Rose BD (1987) Pathophysiology of Renal Disease. 2nd edition, New York McGraw-Hill.

31. Ebaid H, Dkhil MA, Danfour MA, Tohamy A, Gabry MS, et al. (2007) Piroxicam-induced hepatic and renal histopathological changes in mice, Libyan J. Med, 2: 82-89.

32. Vanden BT, Vanlangenakker N, Parthoens E, Deckers W, Devos M, et al (2010) Necroptosis, necrosis and secondary necrosis converge on similar cellular disintegration features, Cell Death and Differentiation, 17: 922-930.

33. Trump BF, Berezesky IK, Chang SH, Phelps PC (1997) The pathways of cell death oncosis, apoptosis, and necrosis, Toxicol Pathol, 1: 82-8.

34. Kerr JF, Wyllie AH, Currie AR (1972) Apoptosis a basic biological phenomenon with wide-ranging implications in tissue kinetics, $\mathrm{Br} \mathrm{J}$ Cancer, 4: 239-57.

35. Kumar V, Cotran R, Robbins S (2002) Robbins Basic Pathology (7th edn.). Philadelphia: Elsevier Saunders.

36. Traditional and Modern Medicine Research Directorate; Ethiopian Health and Nutrition Research Institute, and Faculty of Veterinary Medicine; Addis Ababa University. Evaluation of plant based medicines used for the control of major animal ectoparasites: Proceedings of the Workshop on Evaluation and Future Directions. March 31, 2010, Addis Ababa, Ethiopia.

37. Shehata EMS, Mona ME-D, Sherif AA-D, Monir M, Zakaria AA Toxicological Affects of Essential Oils from Eucalyptus Eucalyptus globules and Clove Eugenia caryophyllus on Albino Rats. Polish J. of Environ. Stud. 2011; 20(2): 429-434. 